\title{
The Globalization of \\ Rhetoric \\ and Its Discontents
}

Steve Fuller

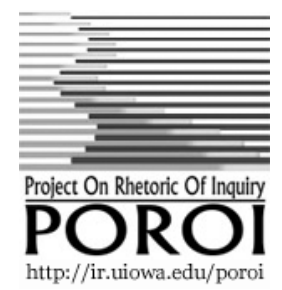

Poroi, 2, 2, November, 2003

1 The title evokes both sides of an important argument and the frame I recommend for seeing it. The argument is between those who support and those who resist turning "rhetoric" into an academic free-trade zone. In this issue of Poroi, Herbert Simons has renewed his call for trade liberalization, this time under that very rubric. ${ }^{1}$ In response, I renew and specify the case for a strategic protectionist policy. This includes evoking the perils that await the naïve free trader, as described by J oseph Stiglitz on the basis of his recent stint as Chief Economist at the World Bank. ${ }^{2}$ The worry is that the Simons regimen would turn rhetoric into an intellectually debt-ridden, third-world power in the academic world.

2 As Simons points out, the debate has been triggered by his review of a book edited by Alan Gross and William Keith. ${ }^{3}$ In the earlier round of controversy, I joined several of the book's contributors in reply. ${ }^{4}$ In line with the old Quaker adage, "My enemy's enemy is my friend," our response reflected an uneasy alliance of disparate elements that, on other occasions, would have been at odds. In his current piece, not surprisingly, Simons exploits some of the internal disagreements that had to be papered over to face the common foe of rhetorical globalization. Here I break cover and write exclusively under my own name.

3 For didactic purposes, though, let me begin by highlighting one defining tension in our original response to Simons. Perhaps this is represented best by comparing Michael Leff to Alan Gross. Both defend rhetorical protectionism, but on radically different - even mutually opposed - grounds.

4 Leff draws on criteria of legitimate lineage: Rhetoric is whatever can be shown to have descended from the classical tradition of public address. As might be expected of a family whose members have bred freely over many centuries, there are many mongrels along the way. Leff holds that it is possible nevertheless, on relatively strict genealogical grounds, to say that certain ideas or 
practices are "more" or "less" rhetorical.

5 Gross would protect rhetoric by turning it into a kind of Kuhnian normal science. This converts the concepts of classical rhetoric into analytic techniques that can be unleashed on virtually any unsuspecting text to produce a distinctly "rhetorical" brand of research. Gross himself specializes in science, though other rhetorical technicians might specialize in politics, cultures, etc. What these rhetorical technicians share is a set of tools and a worldview that takes the tools to be suitable for interesting work.

6 Notice that Leff and Gross each presume a sense in which rhetoric is "global," yet neither accepts Simons's indiscriminate (globalized?) sense of the word. Gross may regard rhetoric as a specific set of intellectual tools with universal applicability, but it does not follow for him that every application is competent, let alone brilliant. Formal training in the relevant paradigms normally is required. Leff finds rhetoric pervasive in current society as a key component of the West's cultural heritage. It does not follow for him, however, that rhetoric is a kind of communicative aether, spread uniformly throughout society. After all, public matters - the classical site of rhetoric - do not exhaust today's interests and activities. When it comes to public concerns, though, rhetoric displays a unique sensitivity.

7 Gross and Leff would sell rhetoric as radically different goods: Gross as expert research, and Leff as moral instruction. But together they share a keen sense of the economist's idea of comparative advantage in the marketplace of ideas: What is it that rhetoricians can provide more effectively than anyone else, to turn potential competitors into customers? As David Ricardo first showed 200 years ago, it is only when every potential trader addresses this question that effective free trade can result. For his part, Simons simply fails to recognize the question. Consequently his advice to rhetoricians seriously imperils the future of the discipline.

8 We can imagine Simons as leading a culturally rich but economically poor country. He is trying, in effect, to persuade his people to accept the International Monetary Fund's conditions for financial aid. These involve the immediate removal of trade barriers, allowing foreign firms to compete with domestic ones on an equal footing. The result is likely to be one more disaster of the sort that Stiglitz documents and, more important, claims could have been easily predicted. ${ }^{5}$ 
9 To follow the Simons advice would be to enable cultural studies, literary criticism, and social theory to flood the market for rhetoric. These would employ some rhetoricians as their agents, but most professional rhetoricians would struggle to provide cheaper - less intellectually demanding? - versions of what those other disciplines can provide. The traditional, distinctive strengths of rhetoric would be left to languish in relative isolation and poverty. A shrewder policy is for rhetoric to develop its domestic, distinctive strengths to the point that people from outside the discipline would lack the capacity and the interest to compete on that terrain. Much of the task is for rhetoric to reclaim intellectual ground that it already has lost to its closest rivals. This phenomenon roughly tracks the shrinkage of the public sphere. ${ }^{6}$

10 I do not wish to deny that a free market for ideas is a beautiful concept to which we all aspire. But it requires a certain social world for its realization, and Simons shows no recognition that we do not (yet) live in such a world. Civic-republican ends in the academy cannot be achieved by banana-republican means. ${ }^{7}$ Simons rightly detects anger as the emotional vector that guides the initial response by several of us to his review of Rhetorical Hermeneutics. It is the anger that led Marx and Engels to distinguish their own "scientific socialism" from the "utopian socialism" of their fellow progressives.

11 Life on Planet Simons seems to consist of NCA meetings where professional rhetoricians tell heart-warming tales of resonances, synchronies, and synergies between their work and the work of denizens in trendier precincts of the academy. Occasionally a leader in the field like Simons himself can get a few of these people - sometimes by paying them -- to share a podium or a volume with professional rhetoricians. Nevertheless the surface dazzle fades once we consider the balance of intellectual trade between rhetoric and its rivals. It remains largely one-way, to the detriment of rhetoric, and the Simons prescription likely would aggravate the imbalance.

12 The Simons arguments for liberalizing trade rest of a peculiar, pragmatist reading of intellectual history. Before turning to their intellectual substance, though, I want to draw attention to their sanguine attitude toward the current condition of rhetoric as a discipline. It exemplifies a deep problem that the field needs to address more systematically than it has. Put bluntly, Simons's training in rhetoric has not enabled him to make sound judgments 
about the success or failure of his own discipline.

13 Perhaps the normative dimension most characteristic of rhetoric is defined by the poles of "success" and "failure." This dimension might be easiest to assess when an audience listens to a speaker then responds - by applause, grumbles, or decisions. This is the paradigm for public address. Attenuate or suspend the paradigm's assumptions, and it becomes less clear what counts as success or failure. For knowledge claims in academic forums and publications, it becomes radically unclear. In fact, the intuitions of professional academicians about epistemic success and failure are generally unreliable, mainly because their standards are inconsistent across judgments. Sometimes they base their judgments on citation counts, sometimes grant amounts, sometimes student enrolments, sometimes "the word on the street," etc. And what are the relevant time frames?8

14 Academic administrators and science policymakers dispatch these problems daily with characteristic expedience. Moreover those who study knowledge production from an empirical or historical standpoint know that this is how such problems are typically solved. For that reason, they typically deny that talk about success and failure can ever rise above the level of preference and prejudice in the face of sheer contingency. As long as rhetoric accepts this verdict, however, it denies itself access to a distinctive part of its own heritage, one potentially high in market value. In the final section, I argue that the sense of "success" relevant for evaluating rhetoric's performance is the capacity to turn mere things into public things.

\section{Against Pragmatist Complacency}

15 The most challenging arguments in the Simons defence of rhetorical globalization trace to Edward Schiappa, a self-styled "terminological Darwinist" and "pragmatist." I reach for my wallet whenever "Darwinist" and "pragmatist" appear outside their technical contexts of current biological research and earlytwentieth-century American philosophy. In more extended usage, these terms too often license complacent assertions suited to Dr. Pangloss. For example, Schiappa draws a historical analogy between the fate of the claim that "everything is physical," first enunciated by the pre-Socratic philosophers, and the fate of the Simons Doctrine that "everything is rhetorical." Recall how Schiappa puts the analogy: "Now, 2600 years later, most of the sciences are still informed by the general notion that almost 
everything can be described as "physical." Where is the problem? When was "physics" ever in danger of losing its disciplinary authority?"9 Implied here, of course, is that the history of physics teaches us that rhetoric has nothing to fear from globalization. Unfortunately the history of physics - and of science more generally - teaches us quite the contrary.

16 The discipline that we call "physics" conceives physical reality as the result of fundamental forces and particles well beyond the threshold of ordinary perception. Only in the twentieth century did it come to be the authoritative voice on what we normally call "physical reality." To be sure, articulated conceptions of invisible forces and particles can be found among the ancients; and certainly the great scientific revolutionaries Galileo, Boyle, and Newton took such things seriously. Although these views now strike us as highly "modern," they struck most ancient philosophers and early modern scientists as "occult." This hostility to the occult views of physicists reached its peak in the nineteenth century, when a combination of philosophical and phenomenological arguments (mostly from chemists) claimed to show that our commonsense experience - of, say, the solidity of objects - had to remain veridical in any ultimate explanation of physical reality. The explanation we believe today - that a wooden table is "really" some atoms buzzing around very fast in a void - was held to be a non-starter.

17 There are remnants of this sensibility. By the early 1980s, the occult entities proffered by physicists had already received several decades of experimental demonstration. Yet, as a Ph.D. candidate in history and philosophy of science at the University of Pittsburgh, I ran across an "ordinary language" philosopher who insisted that relativity and quantum mechanics are "conceptually confused" because they do not respect the "facts" of our everyday experience of space and time. We graduate students were told to tiptoe around the philosophical dinosaur until he retired.

18 The lesson for rhetoric is harsh: No particular discipline - no kind of discipline - has a permanent lock on any part of reality. By this I mean something stronger than the rosy scenario envisaged by Schiappa and Simons, whereby the originating discipline (i.e., rhetoric) may later need to share authority with newcomers (e.g., cultural studies) who provide complementary modes of access to a common reality. Rather I mean that the upstart disciplines may simply usurp the common terrain and 
leave the old-timers with a stark choice: imitation or extinction.

19 Chemistry has been applied physics for only about 100 years. Before that, it competed with physics to provide the fundamental account of physical reality. Theirs was a battle of "energy" versus "atoms." 10 To the intuitive rhetorician, moreover, chemistry had all the initial advantages. These included a tighter grip on common sense and practical applications. At least in the nineteenth century, however, chemists worked in settings as different as factories and universities, with their status and even ideology typically tying more closely to their place of work than to an overarching disciplinary identity. (It is not by accident in The Structure of Scientific Revolutions that Kuhn stops referring to chemistry after 1850.) Chemists lacked the collective identity of the physicists, who insisted on a specific kind of resolution for scientific disputes. This generation and explanation of phenomena in certified laboratories became the gold standard for academic authority in the twentieth century.

20 The physicists were hardly alone in doing experiments, but they argued persuasively that these were the keys to everything else. They succeeded in turning "physical reality" into an object of expertise. As a classical rhetorician like Leff might put it, this removed the investigation and determination of "physical reality" from the public sphere.

21 To my eyes, Simons looks like he would take rhetoric down the route of chemistry. Of course, it is a science still concerned with physical reality and still credited with significant practical import. Yet no philosopher of science has made a reputation primarily as a philosopher of chemistry. This suggests that the discipline is seen to lack its own distinctive intellectual problems. Chemists increasingly re-brand themselves as "nanotechnologists" in a desperate attempt to corner the grey area where basic research funding overlaps with popular science fiction. The diminishing numbers of students enrolled in chemistry courses hint that chemistry is a word shrinking in reference. People still believe that chemistry constitutes the world without necessarily believing that the world must contain chemists. In this sense, physicists, molecular biologists, even engineers are all competent in chemistry - and do more interesting things than the people officially called "chemists." Similarly it might be said that, in a Simonized academy, rhetoric would still exist but without requiring the specific ministrations of rhetoricians who are 
distinguishable from other humanists and social scientists.

22 "Surely it couldn't happen here" might be the instinctive response to my call to arms. Don't be so sure. A folk sense of intellectual history peddled by people like Richard Rorty says that counterintuitive scientific concepts gradually come to be assimilated into public discourse, ultimately becoming part of society's knowledge base. Yesterday's nonsense becomes tomorrow's common sense.11 As a matter of fact, intellectual history is not so obliging. It would be seriously misleading to say that the Copernican worldview has become our common sense. Rather we have learned to discount our intuitive views about physical reality, which still lead us to think that the sun moves around the earth, in favor of the Copernican view. Most educated people now promptly assent to Copernicanism without claiming to possess any direct evidence for its truth.

23 For 500 years, society has ceded epistemic ground gradually from common sense to a kind of expertise strongly associated these days with physics. Relativity theory and quantum mechanics are only extreme versions of this tendency: educated people assent nowadays to cutting-edge physical theories not only without ever having experienced their distinctive consequences but also without ever having mastered their exact contents. ${ }^{12}$ Admittedly the consequences occur well beyond ordinary human perception, but presumably the contents are not beyond ordinary human intelligence.

24 What are the implications for rhetoric? Look at the schizoid career structure of academicians in rhetoric and communication studies. At the undergraduate level, traditional courses in public address and technical writing still dominate the curriculum and often keep the entire department afloat. These courses portray the rhetor as someone with considerable agency - that is, someone who enjoys significant control over status, material, and audience. Such assumptions befit an elite communicator in a contained space. This is a remnant of a bygone - and perhaps lamented - era, but it is hardly representative of the world where the students and their teachers live. Luckily, at least for the sanity of the professional scholars in this field, there are graduate courses devoted to systematically dissolving just these assumptions. What is asserted to the many in the light of day is routinely denied by the few at dusk. From the Frankfurt School to French poststructuralism, often aided by the latest social science research, the illusion of a solid public sphere with clear channels of 
communication is revealed to be a dispersion of indeterminate media effects.

25 Sound familiar? Certainly Alan Sokal and J ean Bricmont had no trouble documenting the ways in which many of the French theorists taught in rhetoric graduate courses today have taken a free ride on the rhetoric that physics has used to establish its unique expertise in the twentieth century. ${ }^{13}$ Still my point is very specific: that the discipline of rhetoric pays a high price for trying to follow suit. Literary criticism, cultural studies, and social theory can all survive without a foundational sense of "the public," but it is not clear that rhetoric can.

26 As I suggested earlier, rhetoric could turn into the chemistry of the humanities: denying all intellectual pretension and happy to say, "Let us begin with some false assumptions for practical purposes: suppose there were a public sphere..." Whether this is the spirit for conducting a public-speaking course is another matter, especially given the traditional moral character of rhetorical instruction. It is easy to see why Leff might want to restrict rhetoric's purchase to whatever remains in the public domain. How can you teach public speaking if you do not believe that the public exists? ${ }^{14}$ Yet another way to address this question, a way I prefer, is to have rhetoric reclaim the areas of life and knowledge that have been transferred out of the public sphere.

27 Before I elaborate this project of rhetorical reclamation, we need to consider one more pragmatist plank that the Simons platform for free trade derives from Schiappa. In response to the Simons query about whether rhetoric should retain its classical vocabulary, Schiappa has taken another page out of the Rorty playbook. "We use vocabularies that work for us, that accomplish our ends; and if there are other terms that work better for some reason, so be it. Disciplines progress (for the most part) through greater specialization, and that specialization usually entails a richer and more technical vocabulary. If the language of classical rhetoric no longer does what we need it to do, or if other language works better, again, so be it."15

28 The bland reasonableness of this argument suggests that something is afoot. Schiappa sounds like he is saying that classical rhetoric needs to expand its lexical horizons, importing or coining new words to cover new situations unforeseen by the ancients. In the context of Simons's overall argument, however, Schiappa is really raising the prospect that the classical vocabulary may be 
replaced altogether because other terms - perhaps those imported from cultural studies - can capture better what rhetoricians want to address these days.

29 Our images for "specialization" are telling. The branching "tree of knowledge" comes first to mind. By analogy, it would make classical rhetoric the sturdy trunk or perhaps the buried roots that support and nourish the exfoliating disciplines of cultural studies. But embryology images specialization as forming an organism through a reiterated process of cell division and reorganization. By the time the organism reaches maturity, remnants of its previous stages have virtually disappeared. The analogy for classical rhetoric would be grim: ultimately the discipline will wither away. Ernst Haeckel's famous image of evolutionary speciation, still found in high-school biology textbooks, superimposes embryological division and reorganization on the tree of knowledge. Tree-like lines of descent from the panoply of current species stretch down into ever smaller and simpler groups of organic forms from earlier eras. Yet this third image makes it easy to forget that speciation has been accompanied by extinction. At most, the progenitors enjoy a virtual persistence, since today's species carry most of the same genes. By analogy, traces of ancient rhetoric as a progenitor of cultural studies might be seen in the tropes that remain fashionable in narrative analysis. Is that sufficient disciplinary existence and recognition for rhetoric? Schiappa and Simons seem to think so.

30 The strict free- trade policy for rhetoric rests on an intellectual substratum of complacent pragmatism. What should its troubles teach rhetoric? At a minimum, pragmatism is a fickle friend of rhetoric. Pragmatists usually dwell at extremes between which rhetoric flourishes. Rhetoric demands an ability to grasp and compare alternative courses of action, especially in terms of costs and benefits. No action is either completely determined or free, or an unconditional success or failure. Rhetoric must appreciate how success and failure arise relative to exigencies and audiences, which the good rhetor tries to shape to advantage. With the honourable exception of J ohn Dewey, pragmatism has moved historically in a much cruder space of belief and persuasion than this. ${ }^{16}$

31 Early pragmatism was a philosophy of pure voluntarism and individualism, with William J ames appearing as the American Nietzsche. Especially in his famous 1897 lecture, "The Will to Believe," J ames advised that people should believe whatever works 
for them. For all its philosophical shortcomings, this version of pragmatism at least had the virtue of holding people responsible for what they hold to be true. Recent neo-pragmatism tends to identify truth with what already has been shown to work. In this spirit, despite his protestations to the contrary, Rorty often writes as if an evolutionary sense of survival were a surrogate for truth. Schiappa pursues this complacent line. It encourages a profoundly unrhetorical - and rather fatalistic - attitude toward history. The bare fact that some rhetoricians and their colleagues continue to be gainfully employed is mistaken for disciplinary success that requires no further explanation, let alone improvement. This is a counsel of epistemic desperation: “Rhetoricians wouldn't still be here if we weren't doing something right!" Such attitudes mystify the dimension of success and failure that rhetoricians should work to clarify.

\section{Toward a Rhetorical Reclamation}

32 It might be true that those who can't do teach, but it might be true also that those who do can't teach. That twist of the adage comes to mind with Simons's account of his own practice. He is exactly right to promote the familiar but relatively unrewarded skills of discussion and debate. These remain at the heart of the undergraduate rhetoric curriculum. ${ }^{17}$ Any reclamation of rhetoric's lost ground begins here, but it cannot end here. As more and more of social life eludes the public sphere, his academically staged demonstrations become showpieces. They are entertaining, even informative, for participants and observers; yet they do not connect to the sites or manners for the society at large to decide the questions debated. In terms of the globalization metaphor, the Temple Issues Forum cited by Simons resembles a cultural heritage park or a wildlife preserve in a third-world country where the landscape has been blighted by foreign industry and commerce. It can attract tourists, but it can do little by itself to build the country's capital base for effective competition in the international arena.

33 One person cannot do everything, but Simons's own measure of his pedagogy seems limited to what happens on his campus, whereas rhetoricians can do - and already have done - more. An example is the Science Policy Forum started in 1998 by Gordon Mitchell and Timothy O'Donnell. It began with the American Association for the Rhetoric of Science and Technology. ${ }^{18}$ Mitchell and O'Donnell, two experienced debate coaches, say they were 
inspired by a challenge from a leading climate scientist to create a public debate on global warming. The scientist wanted the U.S. Congress to provide the venue, but Mitchell and O'Donnell translated his challenge into policy resolutions for high-school debates. They simulated the planned public debate, which matched leading adversaries in addressing a resolution that brought out salient differences in their positions. The proceedings enabled multiple media representations, forms of analysis, and channels of dissemination.

34 The AARST Science Policy Forum shows how to reclaim rhetoric's ground. Mitchell and O'Donnell constructed a res publica from people and materials otherwise disorganized rhetorically. The two turned mere things into public things, something only rhetoricians are inclined and able to do. ${ }^{19}$ Cynics may dismiss such an exercise as ultimately ineffectual in a political culture where issues like global warming are decided by legislators several levels removed from the rhetorical activists. Yet the very activity of constructing public things can sweep up large numbers of people and ideas, transforming them into a whole somewhat greater than the parts. This has been the traditional argument for participatory democracy: not that it generates the best outcomes most efficiently but that it improves the society's individual and collective intelligence. ${ }^{20}$ To mimic trendy management-speak, we might say that rhetoricians engage in "democratic capacitybuilding."

35 Rhetoric's reclamation of the public sphere does not stop with this. With global warming, the main obstacles to effective rhetorical activism involve the status of the activists as relatively minor players in the U.S. Congressional arena. Rhetorical activists have a better chance of influencing aspects of governance devolved to state and local levels. A striking feature of the United States compared to other developed countries is its disposition to decide educational matters locally. To the rest of the world, the institutional diversity that characterizes primary, secondary, and tertiary education in the U.S. looks like the one clear case in which the invisible hand actually works. Most developed countries have a national education ministry that sets a common curriculum and administers examinations for assigning students to schools at the tertiary or even secondary levels. The lack of centralization in American education means that there are more opportunities for rhetorical activism. Especially this can come in constructing locally binding social experiments from which others - inside and outside the locale - can learn, raising the overall level of play in 
the public arena.

36 A case in point is a growing intellectual movement propelled importantly by the discipline of rhetoric as practiced in the United States. Yes, Intelligent Design Theory is controversial. The pervasive caricature of IDT as old Creationist wine poured into new scientistic bottles might leave rhetoric reluctant to associate itself with IDT's "success." Yet there might not be another movement with such explicit links to the rhetorical tradition that in recent years has done so much to reclaim for public deliberation matters earlier ceded to technical expertise. ${ }^{21}$

37 From a sociological standpoint, it is not surprising that IDT turns out to be a clear success for rhetoric. The location of rhetoric departments is heavily biased toward parts of America with strong populist traditions - on both the left and the right of the political spectrum. Moreover the authority of science in the United States links so closely to Big Money from Big Government and, increasingly, Big Business that it becomes an obvious target for populists. That Washington still leads the research agenda (through the NSF, NIH, etc.) yet localities set curricula can make almost inevitable populist revolts over some aspects of science. Battles arise over biology textbooks because they are where Big Science impinges on our very identity as human beings.

38 This account of IDT ignores Christian fundamentalism and creationism. As debates over Darwinian theory increase in philosophical and scientific sophistication, references to Genesis yield to arguments from probability theory and questions about species classification. IDT has yet to score a knock-out punch against the Neo-Darwinian synthesis, but has begun to erode its credibility as a hegemonic authority on the nature of life. As philosophers and scientists contest the latest versions of IDT, the arguments reveal a presumption that IDT must outdo - not merely equal - Darwin in the explanatory sweepstakes. This, then, reveals a problem of epistemic fairness: Why must the pursuit of science be defined in zero-sum terms? Why must IDT supporters convert Darwinists to achieve legitimacy? Should Darwinists enjoy a state-licensed monopoly over biology? The presumption challenged in these three questions is probably the most pernicious legacy of Kuhn's theory of scientific change: namely that the existence of a single dominant paradigm is a necessary condition for science. ${ }^{22}$

39 A more democratic and intellectually productive presumption is 
that, where doubts remain about how best to explain something, alternative lines of inquiry should be promoted, especially if they would take what is currently known into significantly different domains. The ongoing development of IDT may provide the template for further rhetorical activism in relation to science. This suits budget-conscious times when research funds shift from federal agencies to local authorities and the private sector. The rationale for such a reclamation of science for public deliberation may take the following form:

Science is the publicly recognized authority on matters of knowledge.

Yet scientists claim that a large part of what much of the public believes is not only false but also unworthy of public discussion.

These undiscussable topics include basic elements of people's self-understanding, even self-worth, so that the proscriptions impede people's ability to function in public affairs more generally.

Therefore scientists undermine the credibility of science as public knowledge.

To implement a counter-strategy on a large scale could lead to what I call the secularization of science, a phenomenon analogous to the Protestant Reformation. ${ }^{23}$

40 The project of rhetorical reclamation is not simply about reseeding the public interest where it has been crowded out by creeping expertise. It is also about creating new areas of public concern from topics currently submerged in the watery rhetoric of expert agreement. Leah Ceccarelli's work provides a useful, if unwitting, backdrop. She reveals how major scientific research programs have mobilized cross-disciplinary constituencies by suppressing potential disagreements. Typically the coalitionbuilders exploit ambiguities latent in the polysemous terms significant to all the relevant disciplinary partners. ${ }^{24}$ As Ceccarelli shows, the Neo-Darwinian synthesis coalesced around just such a strategy. ${ }^{25}$ The reclamation of rhetoric requires that this strategy be made subject not only to scholarly study but public scrutiny as well. 
41 At least since Thomas Henry Huxley's 1893 Romanes Lecture, "Evolution and Ethics," evolutionists have known that Darwin's theory of natural selection fits uneasily with the ideals of modern medical science to preserve and extend life regardless of cost. Huxley, himself a trained surgeon, urged that medical researchers replace the evolutionary ethic of "survival of the fittest" with the ethic "to fit for survival." There have been sporadic attempts since to forge a field of "Darwinian medicine," but evolutionary biology and biomedical science still differ significantly in content and orientation. Even within the core disciplines of the Neo-Darwinian synthesis, old theoretical and methodological antagonisms between genetics and ecology continue to simmer, and they often come to a boil on biotechnology concerns such as genetically modified organisms.

42 It is always a mistake to imagine that a scientific paradigm like Neo-Darwinism consists of several well-articulated bodies of knowledge interrelated by the rules of logical deduction. It is a mistake even for Newtonian mechanics. A paradigm is little more than an extended exercise in interdisciplinary diplomacy, where the parties realize mutual advantage by playing up agreement and playing down disagreement. An advantage of this strategy is the collective authority that the cross-disciplinary coalition can exercise.

43 In that situation, the rhetorician interested in reclaiming the public sphere must expose ambiguities, uncertainties, contradictions, and incoherences latent in the coalition. Why? Not to sow scientific discord for its own sake or to delegitimate science, but to show sciences as more open to disagreement than they appear when seen through rigidly crafted Kuhnian lenses. The different fields of life science now hang together loosely. They can be picked and mixed to form diverse research programs. None need spell the end to "civilization as we know it," and some can significantly realign the epistemic status of disciplinary practitioners. The rhetorician is not responsible for conjuring up alternative sciences whole cloth. But the rhetorician should be able to pose telling questions to scientific experts. These should place their differences in open view and force them to offer more publicly accessible stories on why we should take all - as opposed to just some -- of them seriously. Since we cannot all become experts, experts must learn how to deal with all of us. Such is the project of rhetorical reclamation. ${ }^{26}$ 
(c) Steve Fuller, 2003.

\section{Notes}

1 See Herbert Simons, "The Globalization of Rhetoric and the Argument from Disciplinary Consequence," Poroi, 2, 2, November, 2003, http:// inpress.lib.uiowa.edu/ poroi/papers/ simons031101.html.

2 See J oseph Stiglitz, Globalization and Its Discontents, New York, Norton, 2002.

3 See Alan Gross and William Keith, eds., Rhetorical Hermeneutics: Invention and Interpretation in the Age of Science, Albany, State University of New York Press, 1997.

4 See Herbert Simons, "Rhetorical Hermeneutics and the Project of Globalization," Quarterly J ournal of Speech, 85, 1, February 1999, pp. 86-100; William Keith, Steve Fuller, Alan Gross, and Michael Leff, "Taking Up the Challenge: A Response to Simons," Quarterly J ournal of Speech, 85, 4, November 1999, pp. 330-338.

5 Stiglitz, Globalization and Its Discontents, especially pp. 59ff.

6 Simons attributes the "reclamation" metaphor to Dilip Gaonkar, "Rhetoric and Its Double: Reflections on the Rhetorical Turn in the Human Sciences," The Rhetorical Turn, Herbert Simons, ed. Chicago, University of Chicago Press, 1990, pp. 34166 , on p. 351. Gaonkar wrote about the recent reclamation of rhetoric's sophistic tradition largely by those outside the discipline, whereas I am concerned with the rhetoric's reclamation of the public sphere from many of the same outsiders.

7 On the problems involved in turning science into a civic republican polity, see Steve Fuller, The Governance of Science: Ideology and the Future of the Open Society, Milton Keynes UK, Open University Press, 2000.

8 I have not even mentioned the most problematic, yet perhaps most common, criteria of "success" invoked by rhetorical critics. These appeal exclusively to the literary qualities of an allegedly successful text. The results can sometimes be profoundly misleading. I discuss these in Steve Fuller, "'Rhetoric of Science': Double the Trouble?" Rhetorical Hermeneutics, pp 279-298. Readers are invited to contrast the accounts of E. O. Wilson's work 
given by Leah Ceccarelli and Ullica Segerstrale: Ceccarelli, "Uniting Biology and the Social Sciences: A Rhetorical Comparison of E.O. Wilson's Conslience and Theodosius Dobzhansky's Mankind Evolving," Poroi, 1, 1, J anuary, 2001, http://inpress.lib.uiowa.edu/ poroi/papers/ ceccarelli. 010101.html; Segerstrale, Defenders of the Truth: The Sociobiology Debate, Oxford, Oxford University Press, 2000. Ceccarelli portrays sociobiology as a rhetorical failure, Segerstrale as a success. Segerstrale's assessment is more accurate, yet this error in judgment does not detract from the overall value of Ceccarelli's work, which is discussed in the final section of the present essay.

9 Edward Schiappa, "Second Thoughts on the Critiques of Big Rhetoric," Philosophy and Rhetoric, 34, 3, 2001, pp. 260-74, on p. 264.

10 Readers interested in what the "path not chosen" might have looked like should consult the wide-ranging works of the 1909 Nobel Prize winner in Chemistry, Wilhelm Ostwald (1853-1932). He used "energeticism" to update Goethe's Naturphilosophie, while linking thermodynamics and moral instruction -- as in the New Commandment to "Always conserve energy!" -- in ways that bear more than a passing resemblance to Taylorist management principles. On the final debate between Max Planck and Ernst Mach, which established the hegemonic authority that physics currently enjoys over physical reality, see Steve Fuller, Thomas Kuhn: A Philosophical History for Our Times, Chicago, University of Chicago Press, 2000, pp. 96-149.

11 See Richard Rorty, Philosophy and the Mirror of Nature, Princeton, Princeton University Press, pp. 315-33. This is Rorty's gloss on the larger import of Kuhn's incommensurability thesis.

12 Science and technology studies scholars, following the lead of Bruno Latour, have sweetened this bitter pill by dubbing cases where common sense gets ceded to expertise as "delegation." This probably implies greater intention and effectiveness on the part of the "delegators" than warranted. More critical readers of Latour might wish to read "delegation" as "colonization."

13 I am referring, of course, to Alan Sokal and J ean Bricmont, Intellectual Impostures, London, Phaidon, 1998, published in the U.S. as Fashionable Nonsense. 
14 For an exceptionally probing inquiry into this "dark night of the soul" question, see William Fusfield, "Refusing to Believe It: Consideration on Public Speaking Instruction in a PostMachiavellian Moment," Social Epistemology, 11, 3-4, 1997, pp. 253-314.

15 Schiappa, as quoted in Simons, "The Globalization of Rhetoric," paragraph 28. For an antecedent, see Richard Rorty, Objectivity, Relativiam, and Truth, Cambridge, Cambridge University Press, 1991, pp. 126-150.

16 Here I allude to ongoing work by William Keith, the guiding light behind the original "Response to Simons." Keith is completing a book (with a working title of Discussion as Democracy: Speech, Civic Education and the Forum Movement) on the Discussion Movement and the Forum Movement, which were early twentieth-century attempts to wed Dewey's vision of participatory democracy to the courses in public speaking and debate taught in the rhetoric departments then emerging in the U.S.

17 Simons, "The Globalization of Rhetoric," p. 35.

18 The complete text of the Science Policy Forum debate and commentaries appeared in Social Epistemology, 14, 2-3, 2000.

19 This point cannot be stressed too much. In recent years, I have been promoting the use of consensus conferences and citizens juries as a means of democratizing the science policy process. While quite happy to study these decision-making bodies, most of my colleagues in science and technology studies (outside of J apan, interestingly) are reluctant to endorse or even try to improve them. They have two reasons: (1) they are empirical researchers and "therefore" not public advocates, and (2) they doubt that any particular institutional innovation can decisively democratise science. Behind the second reason is a more global skepticism about the efficacy of democratic institutions. Had this been present in Athens of the fourth century bce or Britain of the seventeenth century ce, it would have nipped democracy in the bud.

20 One recent comprehensive defence of this position is Benjamin Barber, An Aristocracy of Everyone, New York, Ballantine Books, 1992. 
21 An excellent history, told from the standpoint of a rhetorically trained participant-observer, is Thomas Woodward, Doubts about Darwin: A History of Intelligent Design, Grand Rapids, Baker Books, 2003.

22 This is one of my main examples of the baleful influence that Kuhn has had on our understanding of science. See especially Fuller, Thomas Kuhn, pp. 379-424.

23 See Steve Fuller, Science, Minneapolis, University of Minnesota Press, 1997, pp. 60-62.

24 Leah Ceccarelli, Shaping Science with Rhetoric: The Cases of Dobzhansky, Schroedinger, and Wilson, Chicago, University of Chicago Press, 2001.

25 This aspect of Ceccarelli's thesis is also available as "Uniting Biology and the Social Sciences."

26 This explicitly sophistic and dialectical approach to rhetoric is defended in the new edition of Steve Fuller and J ames Collier, Philosophy, Rhetoric, and the End of Knowledge: A New Beginning for Science and Technology Studies, Hillsdale, NJ , Lawrence Erlbaum Associates, 2003. 